УДК 378.016:78-051:37.015.31

DOI https://doi.org/10.31723/2524-0447-2020-30-2-34

\author{
Гун Вейді \\ ORCID: 0000-0002-3376-0239
}

аспірантка кафедри образотворчого мистецтва, музикознавства та культурологіі

Сумського держсавного педагогічного університету

імені А. С. Макаренка

akosorich@gmail.com

\title{
ОСОБЛИВОСТІ ПСИХОМОТОРИКИ ДИРИГЕНТА ХОРУ В КОНТЕКСТІ МУЗИКОЗНАВЧОГО АНАЛІЗУ
}

\begin{abstract}
Мета дослідження - визначити особливості формування рухових навичок диригента хору в аспекті його психомоторних якостей. Методологія дослідження - для досягнення мети в роботі використано комплекс взаємопов'язаних методів, таких як аналітичний - для аналізу й обробки українських $і$ закордонних наукових праць із психолоzії, психофізіології, фізіології ВНД, культурології, мистецтвознавства, в яких розглянуто діяльність диригента хору через призму психофізіологічних аспектів рухової активності та психомоторики; теоретичний - для систематизації наукових поглядів $i$ підходів до визначення психомоторики як складової частини диригентської діяльності, узагальнення мистецтвознавчого та психофізіологічного доробку провідних учених; системно-структурний - для структурування складових елементів психомоторики в аспекті діяльності диригентів хорового колективу; узагальнення - для формулювання положень із психології, психофізіології, музикознавства, фізіології, педагогіки та висновків роботи. Наукова новизна полягає у виявленні складових елементів психомоторики диригента хору, які базуються на психологічних і психофізіологічних засадах виявлення впливу психофізіологічних процесів на формування психомоторики диригента хору. Висновки. На основі узагальнення мистеитвознавчих і психофізіологічних підходів до специфіки діяльності диригента хорового колективу ми дійшли таких висновків: гармонійний розвиток рухових якостей диригента має спиратися на знання психофізіології, фізіології рухового апарату людини, психомоторики, психології та базуватися на розвитку функціонального диригентського жесту, що є синтезом слухової інформації, кінестетичної інформації (стандартів диригентських рухів), візуалізації графіки руху диригентської аплікатури, полімодальності (орієнтації в елементах графічних, кінестетичних, візуально-просторових диригентських жкестів). Отже, віддзеркалення рухової моделі музичного твору через опрацьовану партитуру та на-
\end{abstract}

(C) Гун Вейді, 2020 
дання емоційного тонусу твору є основою диригентської діяльності. Під час відтворення драматургії музичного твору диригент хору застосовує мануальну техніку, яка грунтується на психомоторних принципах, психофізіології та фізіології м'язової системи. Створення художнього образу музичного твору базується на психологічному рівні, що реалізується через психомоторику та психофізіологічні особливості диригента хору, які шляхом перенесення (ілюстрації) сприймаються учасниками хорового колективу. Доведено, що найскладніше завдання діяльності диригента хору - рухове проектування драматургії твору та його віддзеркалення в диригентських рухах, які моделюють і відтворюють звукообразний код музики шляхом диригентських навичок музиканта.

Ключові слова: диригент хору, мануальна техніка, діяльність диригента, психомоторика, творчий процес, партитура, драматургія.

Gun Veidi, Postgraduate Student at the Department of Fine Arts, Musicology and Cultural Studies of the Sumy State Pedagogical University named after A. S. Makarenko

Features of the psychomotor skills of a choir conductor in the context of musicological analysis

The purpose of the study is to determine the features of the formation of motor skills of the choir conductor in terms of its psychomotor qualities. Research methodology - to achieve the goal a set of interrelated methods is used, namely: analytical - for analysis and processing of Ukrainian and foreign scientific works on psychology, psychophysiology, GNI physiology, culturology, art history, which examines the activities of the choir conductor through the prism of psychophysiological aspects of motor activity and psychomotor skills; theoretical - to systematize scientific views and approaches to the definition of psychomotor as a component of conducting activities, generalization of art and psychophysiological achievements of leading scientists; system-structural - for structuring the constituent elements of psychomotor in terms of the activities of choir conductors; generalizations for the formation of provisions on psychology, psychophysiology, musicology, physiology, pedagogy and conclusions. Scientific novelty is to identify the components of psychomotor skills of the choir conductor, which are based on psychological and psychophysiological principles of identifying the influence of psychophysiological processes on the formation of psychomotor skills of the choir conductor. Conclusions. Based on the generalization of art and psychophysiological approaches to the specifics of the choir conductor, we came to the following conclusions, namely: the harmonious development of motor qualities of the conductor should be based on knowledge of psychophysiology, physiology of human musculoskeletal, psychomotor, psychology and based on functional development. synthesis of auditory information, kinesthetic information (standards of conducting movements), visualization of the graphics of the conductor's fingering, polymodality (orientation in the elements of graphic, kinesthetic, visual-spatial conducting gestures). Thus, the reflection of the motor model of a musical work through the processed score and giving the emotional tone of the work is the basis of conducting. When recreating the 
drama of a piece of music, the choir conductor uses a manual technique based on psychomotor principles, psychophysiology and physiology of the muscular system. The creation of an artistic image of a musical work is based on the psychological level, which is realized through the psychomotor skills and psychophysiological features of the choir conductor, which are perceived by the members of the choir through transfer (illustration). It is proved that the most difficult task of the choir conductor is the motor design of the work's drama and its reflection in the conductor's movements, which model and reproduce the sound-like code of music through the musician's conducting skills.

Key words: choir conductor, manual technique, conductor's activity, psychomotor skills, creative process, score, dramaturgy.

Гун Вейди, аспирантка кафедры изобразительного искусства, музыковедения и культурологии Сумского государственного педагогического университета имени А. С. Макаренко

\section{Особенности психомоторики дирижера хора в контексте музыковедиеского анализа}

Цель исследования - определить особенности формирования двигательных навыков дирижера хора в аспекте его психомоторных качеств. Методология исследования - для достижения цели в работе использован комплекс взаимосвязанных методов, таких как аналитический - для анализа и обработки украинских и зарубежных научных работ по психологии, психофизиологии, физиологии ВНД, культурологии, искусствоведению, в которых рассмотрена деятельность дирижера хора через призму психофизиологических аспектов двигательной активности и психомоторики; теоретический - для систематизации научных взглядов и подходов к определению психомоторики как составляющей дирижерской деятельности, обобщения искусствоведческих и психофизиологических наработок ведущих ученых; системно-структурный - для структурирования составных элементов психомоторики в аспекте деятельности дирижеров хорового коллектива; обобщения - для формирования положений психологии, психофизиологии, музыковедения, физиологии, педагогики и выводов работы. Научная новизна заключается в выявлении составляющих элементов психомоторики дирижера хора, основанных на психологических и психофизиологических аспектах выявления влияния психофизиологических процессов на формирование психомоторики дирижера хора. Выводы. На основе обобщения искусствоведческих и психофизиологических подходов $\kappa$ специфике деятельности дирижера хорового коллектива мы пришли $\kappa$ следующим выводам: гармоничное развитие двигательных качеств дирижсера должно опираться на знания психофизиологии, физиологии двигательного аппарата, психомоторики, психологии и базироваться на развитии функционального дирижерского жеста, что является синтезом слуховой и кинестетической информации (стандартов дирижерских движений), визуализации графики движения дирижерской аппликатуры, полимодальности (ориентации в элементах графических, кинестетических, визуально-пространственных дирижерских жестов). 
Итак, отражение двигательной модели музыкального произведения через разработанную партитуру и предоставление эмоционального тонуса произведения является основой дирижерской деятельности. Во время воспроизведения драматургии музыкального произведения дирижер хора применяет мануальную технику, которая базируется на психомоторных принципах, психофизиологии и физиологии мышечной системы. Создание художественного образа музыкального произведения базируется на психологическом уровне, реализующемся через психомоторику u психофизиологические особенности дирижера хора, которые путем переноса (иллюстрации) воспринимаются участниками хорового коллектива. Доказано, что самая сложнная задача деятельности дирижера хора - двигательное проектирование драматургии произведения и его отражсение в дирижерских движениях, моделирующих и раскрывающих звукообразный код музыки путем дирижерских навыков музыканта.

Ключевые слова: дирижер хора, мануальная техника, деятельность дирижера, психомоторика, творческий процесс, партитура, драматургия.

Актуальність теми дослідження. Однією зі складових частин сучасного мистецтвознавства та музичної освіти є психологічний аспект професійної діяльності, який розкриває індивідуально-особистісні якості майбутнього фахівця. Найскладнішим процесом у мистецькій освіті $€$ процес підготовки майбутнього диригента хору. Діяльність майбутнього диригента характеризується великою кількістю складників, які надалі реалізуються в багатогранному професіоналізмі, що базується на психологічних і психофізіологічних компонентах, які створюють загальний контекст творчої співпраці диригента хору та виконавців.

Диригентська діяльність як у професіоналів, так і у слухачів часто супроводжується різними судженнями. Один і той самий музичний твір у різних диригентів під час виконання музичного твору одним і тим самим хором звучить і сприймається по-різному, що є підставою вважати диригентську діяльність руховою містикою [3].

Одним із найважливіших завдань диригентської підготовки є розвиток диригентських рухів відповідно до змісту, характеру музичного твору та виконавської інтерпретації. Реалізація зазначеного завдання є досить складною у зв'язку $з$ недостатньою теоретичною розробленістю, що має негативний вплив на педагогічну практику підготовки диригентів хору. Як зазначає I. Мусін, проблемам «рухових навичок як способу диригування не приділяється відповідної уваги з боку 
дослідників або ж ставляться до них із певним нехтуванням. Що стосується розвитку рухових відчуттів, то щодо них немає ніякої уяви» [6].

У нашій статті ми намагалися звернути увагу на особливості психомоторики диригента хору як складової частини професійної підготовки.

Мета статті - визначити особливості формування рухових навичок диригента хору в аспекті його психомоторних якостей.

Виклад основного матеріалу. Поняття «психомоторика», запропоноване I. Сеченовим, інтерпретується як напрям руху, сила руху, напруженість і швидкість [9].

Проблему формування психомоторики рухів диригента хору слід розглядати через призму постулатів С. Рубінштейна, сутність яких полягає в тому, що центром діяльності є не засвоєна операція, а ті психічні та психофізіологічні процеси та їхні якості, які й регулюють будь-яку операцію [8]. Тож рухова складова частина диригентської діяльності є різновидами психомоторної діяльності, в контексті якої моторика (рухова діяльність) об'єктивно проявляється через сенсорні системи, рухову уяву (проектування рухів), музичну й образну пам'ять, самоконтроль.

Одним із аспектів підготовки студентів до диригентської практики є взаємокоординація рухової активності з руховою пам'яттю та пам'яттю рухів; зазначений аспект є складником психомоторних процесів [5].

Згідно з дослідженнями О. Запорожця внутрішня моторика (уявлення траєкторії руху) - це можливість уяви індивіда про можливі рухові дії у просторі, що характеризуються направленістю, мотивацією особистості [4]. Є. Іллін справедливо вказує на провідну роль інтелектуальної складової частини психомоторики, а саме рухову пам'ять і пам'ять рухів. Екстраполюючи основні положення означеної теорії на диригентську діяльність, ми дійшли висновку про те, що основу диригентських рухів утворює не рухова пам'ять (кінетика руху), а пам'ять рухів [5]. Ми спираємося на те, що пам'ять рухів є полімодальною в контексті запам'ятовування рухів за участю слухової, зорової, вестибулярної, тактильної та власне рухової пам'яті.

Візуально-зорова складова частина психомоторики - це зорові образи рухів, які відповідають за віддзеркалення худож- 
нього задуму музичного твору на рівні герменевтичних і семіотичних підходів. Диригентські рухи відповідно до означених підходів формують «диригентський образ», що $є$ взірцевою моделлю зорово-звукової форми віддзеркалення музичного змісту партитури твору, яка підмінює графічну модель диригентських рухів і жестів.

Психомоторика диригента також взаємодіє зі слуховою сенсорною системою, що створює звуковий образ, який супроводжується м'язовою чутливістю рухів, що формують технічність моторної (рухової) діяльності. Таким чином слухова система та м'язові рухові комплекси у взаємодії формують складну компоненту психомоторики диригентської діяльності. Проблеми слухо-моторних (слухо-рухових) взаємодій у диригентській практиці досі не вирішені, проте взаємодія слухових і рухових компонентів (психомоторики диригента) відбувається на свідомому рівні, що дозволяє проводити пошуки факторів, які впливають на становлення та формування «відповідного диригентського образу» хорової партитури.

Відомо, що слухове сприйняття та уявлення хорового звучання не визначає диригентські рухи, а впливає на їх характер, тобто прояв особливостей психомоторної активності майбутнього фахівця-диригента хору, що зумовлено художнім змістом твору та творчими задачами. У цьому процесі пусковим механізмом виступає звуковий образ, який визначає рухову задачу. Слід відзначити, що диригентські рухи, виконуючи роль пускового механізму, повинні відрізнятися певними творчими стереотипами як ідентифікатор певної школи виконавства та майстерності. 3 одного боку, диригентські рухи створюють підгрунтя для формування умовно-рефлекторного акту, який закріплюється слухо-руховими зв’язками, а 3 іншого - рухова активність диригента є частиною художнього втілення та прояву диригентського образу.

Аналіз підготовки студента-диригента хору в аспекті психомоторики вказує на такі компоненти: сенсорний, моторний (руховий) і когнітивно-інтелектуальний. Сенсорний компонент містить у собі слухові, зорові та тактильні відчуття. Руховий компонент психомоторики, який визначається сенсорною складовою частиною, містить м'язові відчуття тулуба, рук, пальців, артикуляції та дихання. Когнітивна компонента характеризується процесом переробки та кодування інформації під час пізнавальної діяльності. 
Для розуміння психомоторики диригента велике значення має вчення про фізіологію рухів людини, віддзеркалене в роботах Н. Бернштейна [1]. Науково-теоретичне обгрунтування технічності рухів диригента базується на основі кільцевого регулювання рухів (рефлекторне кільце), визначення ролі та місці свідомості в роботі рефлекторного кільця рухів формує надійну базу для дослідження проблеми психомоторної діяльності диригента.

Феномен диригентської психомоторики - це поєднання координованих рухових актів із компонентами довільних рухів, що є головним зерном наукового дослідження Н. Бернштейна [1].

Головною особливістю психомоторики є здатність людини віддзеркалювати об’єктивну інформацію про свою рухову активність, здійснювати контроль та управління рухами. У визначені К. Платонова вказується, що психомоторика є основним видом об'єктивізації психіки, де задіяні ідео-моторні акти, емоційно-моторні реакції людського організму [7]. Таким чином, під психомоторними здібностями вчений розуміє «рухові здібності, пов'язані з довільним віддзеркаленням рухової діяльності за рахунок диференційованої чутливості, адекватної рухової уяви, уявою, пам'яттю, що забезпечують ефективне управління рухами та руховими актами на основі точного контролю і саморегуляції» [7].

Розкриваючи здібності в аспекті їх розвитку, С. Рубінштейн відзначає, що «жодна зі здібностей не є актуальною, доки вона органічно не ввібрала в себе систему відповідних суспільно вироблених операцій, а ядро здібності - це не засвоєна операція, а ті психічні процеси, за допомогою яких ці операції та їх функціонування регулюють якість цих процесів» [8].

Аналіз диригентської діяльності з погляду психомоторики показує, що диригентська художня концепція потребує конкретних смислових і моторних рішень. Диригент хору порівняно з іншими музикантами не має фізичної роботи, спрямованої на створення звуку, наприклад, як у піаністів, скрипалів, вокалістів тощо. Створення музики диригентом хору базується не на конкретному звуковому матеріалі, а на основі слухового відчуття та музичного сприйняття художнього образу партитури. Розвиток слухо-зорового сприйняття у майбутнього диригента визначає певні труднощі диригентського виконав- 
ства, тому що фізичну дію «легше засвоїти, ніж психологічну, вона доступніша, ніж невловимі внутрішні відчуття, тому що фізична дія більш зручніша для фіксації, вона матеріальна, «видима»», - зазначає К. Станіславський [10].

Парадокс диригентській діяльності є в тому, що нібито провідна роль належить рухам диригента, але передача інформації від диригента передбачає ряд психологічних факторів, пов'язаних із сенсорною, моторною, когнітивно-інтелектуальною підсистемами психомоторики.

Без сумніву, проблема диригентських рухів $є$ однією 3 головних під час навчання диригентському мистецтву. Складність зазначеної проблеми полягає в тому, що педагог повинен навчити та сформувати у студента систему рухових комплексів на основі психофізіологічних процесів, про які інколи не має повної уяви. У диригентській практиці оволодіння моторними (руховими) вміннями базується найчастіше на звичайному механічному повторі, тобто на тренувальному ефекті під час засвоєння диригентських жестів.

На думку I. Мусіна: «Рухові відчуття $є$ «сполучною ланкою» між музичним уявленням і жестом, дають можливість диригенту відчути процес виконавства, створюють відчуття безпосереднього втілення музичного задуму, сприяють керівництву звуком у межах музичного такту, створюють у диригента відчуття «звуку в руках», допомагають передачі образу музичного руху, допомагають трансформації музичних уявлень виразні жести, слугують засобом розвитку навичок диригування, тощо. Рухи диригента визначають ступінь виконавства. Саме через рухи проявляються всі якості та властивості психіки диригента, його здібності» [6].

Зауважимо, що рухи особистості розкривають форму іiі активності в зовнішньому середовищі, яка забезпечується руховим апаратом. Руховий апарат - це анатомо-фізіологічне поєднання м'язової, кісткової та нервової систем організму людини. В основі рухів лежать фізіологічні механізми, а в системі їх керування - психічні та психофізіологічні. Існування людського організму постійно супроводжується виникненням нових рухів, що асоціюються із психічними та психофізіологічними моделями для певної життєвої ситуації. Таким чином, для диригента рухові акти базуються на відчутті рухів. На думку I. Мусіна: «Розвиток рук диригента проявляється не у швидкості та спритності, а в особливій чутливості» [6]. 
Чутливість у диригентському виконавстві є здатністю до психічного віддзеркалення відчуттів, які ініціюють, підтримують і змінюють рухи диригента під впливом художнього образу. Свідомість у регуляції диригентських рухів фіксує не тільки м'язову складову частину рухів, а й стан органів відчуття, які сприймають музичний твір, а також виконує функцію стратегічного планування щодо кінцевого результату.

Враховуючи різні наукові позиції дослідників щодо розвитку рухової активності майбутніх диригентів, вважаємо правильним шлях розподілу уваги для формування адекватної диригентсько-рухової майстерності на різних рівнях, таких як: слуховий рівень - забезпечує музично-слухове уявлення, рівень моторики - трансформацію музично-слухових у диригентські рухи. Робота над диригентськими рухами повинна відповідати поставленим художнім завданням. Створення художнього образу стосується емоційної роботи виконавців, а у диригента образна площина має бути доповнена руховою активністю (психомоторикою).

Звернемо увагу на роль емоційного статусу як важливої складової частини, що впливає на диригентські рухи під час виконавської діяльності. Основою диригентських рухів $\epsilon$ стійкі взаємозв'язки блоку моторики рухів і художньоемоційного образу, а саме особисте ставлення диригента до художнього твору. Визнання психологічного фактору як основного в моториці диригента хору створює підгрунтя для розширення рамок професійного навчання диригентського мистецтва, тобто йдеться про психомоторну складову частину навчання майбутніх диригентів. Такий підхід дасть змогу: формування рухового образу, вдосконалення сенсорного управління рухами, збереження та відтворення рухових стереотипів, а також забезпечить надійність за умов ускладнення творчої діяльності диригента.

Рухи диригента хору можуть бути розглянуті з позицій статичної та динамічної координації рук. Швидкість реакції, співвідношення рухів, що визначають руховий стиль у диригентській площині; автоматизм рухів, ритм і темп тощо рухи диригента характеризуються надзвичайною динамічністю та різноманітністю. Завдання та цілі, які виникають під час диригентської діяльності, потребують відповідної сенсорної активності для забезпечення рухових відчуттів. Відзначимо, що виконавська майстерність диригента базується на 
складних психофізіологічних процесах, які тісно пов'язані із психомоторикою. Саме психомоторика диригента відіграє провідну роль у музично-виконавській діяльності, поєднуючи музично-слухове уявлення й образно-змістовну сутність твору, що визначає диригентські рухи, які моделюють і відтворюють реальне звучання. Жести диригента хору впливають на якість музичного звуку, тому вміння чути звук і керувати ним за допомогою руки, кисті, специфічністю рухів і їх амплітудою $є$ складовою частиною навчання майбутніх диригентів.

Таким чином, основу диригентської аплікатури становлять рухи рук, кисті, пальців які тісно взаємодіють із вокально-музичною моторикою, саме цей процес і повинен бути покладений в основу роботи диригентського класу.

Використання принципів психомоторики та вокально-музичної взаємодії для формування координаційних стереотипів передбачає наявність у диригентсько-хоровому навчанні спеціальних моторно-рухових вправ, які формували б динамічну та статичну координацію, швидкісну координацію, чіткість рухів, довільне гальмування рухів та особистісний характер рухів.

Формування рухів із позицій психомоторики та фізіологічних механізмів повинно складатися 3 певних прийомів: виявлення опорних рухів, групування рухів, мнемотехніки [2]. Вказані прийоми допомагають розумінню психомоторики рухів і техніки диригента, свідомому управлінню диригентськими рухами, ефективності диригентського руху та м'язовому відчутті диригента хору.

Отже, наукова новизна полягає у визначенні психомоторики в аспекті діяльності диригента хору як фахівця в музично-хоровому мистецтві, що вимагає з'ясувати стан дослідженості означеної проблеми, обгрунтувати наукові уявлення про особливості психомоторної та психічної діяльності диригента, розкрити фізіологічні особливості психомоторики диригентської майстерності в контексті керування музичними колективами.

Висновки. На основі узагальнення мистецтвознавчих і психофізіологічних підходів до діяльності диригента хорового колективу ми дійшли таких висновків: гармонійний розвиток рухових якостей диригента повинен спиратися на знання психофізіології, фізіології рухового апарату людини, психомоторики, психології та грунтуватися на розвитку функці- 
онального диригентського жесту, що є синтезом слухової, кінестетичної інформації (стандартів диригентських рухів), візуалізації графіки руху диригентської аплікатури, полімодальності (орієнтації в елементах графічних, кінестетичних, візуально-просторових диригентських жестів).

Отже, віддзеркалення рухової моделі музичного твору через опрацьовану партитуру та надання емоційного тонусу твору є основою диригентської діяльності. Розкриваючи драматургію музичного твору, диригент спирається на мануальну техніку, яка базується на психомоториці, психофізіології та фізіології м'язової системи. Створення художнього образу музичного твору базується на психологічному рівні, що реалізується через психомоторику та психофізіологічні особливості диригента, які шляхом переносу накладаються на учасників музично-хорового колективу. Найскладніше завдання діяльності диригента - це рухове проектування музичного образу та його віддзеркалення в диригентських рухах, що управляють звучанням музичного твору, підкреслюючи виконавську майстерність диригента.

\section{СПИСОК ЛІТЕРАТУРИ}

1. Бернштейн Н.А. Очерки по физиологии движений и физиологии активности. Киев : Медицина, 1966. 130 с.

2. Венедиктова Н.В. Методические аспекты развития координационных действий психомоторной деятельности студента в процессе обучения дирижированию. Вопросы музыкально-педагогического образования. Вып. 3. 2014. С. 62-65.

3. Готсдинер А.А. Музыкальная психология. Москва : Наука, 1993. $190 \mathrm{c}$.

4. Запорожец А.В. Избранные психологические труды. Развитие произвольных движений. Т. 2. Москва : Просвещение, 1967. 207 с.

5. Ильин Е.П. Двигательная память и память на движения синонимы? Вопросы психологии. 1990. № 4. С. 134-140.

6. Мусин И.А. Язык дирижёрского жеста. Москва : Музыка, 2006. 109 c.

7. Платонов К.К. Проблема способностей. Харьков : Знание, 1972. $350 \mathrm{c}$.

8. Рубинштейн С.Л. Проблема способностей и вопросы психологической теории. Вопросы психологии. 1960. № 1. С. 47-60.

9. Сеченов И.М. Избранные труды. Москва : Изд-во АН СССР, 1954. $774 \mathrm{c}$.

10. Станиславский К.С. Работа актёра над собой : собрание сочинений в 9 т. Т. 2. Москва : Искусство, 1989. 511 с. 


\section{REFERENCES}

1. Bernshnein, N. (1966). Ocherki po fiziologii dvizeniy i fiziologii aktivnosti [Essays on the physiology of movement and the physiology of activity]. Kiev: Medetsina [In Russian].

2. Venediktova, N. (2014). Metodicheskie aspekti razvitiya koordinatsionnikh deistviy psikhomotornoi deyatelnosti studenta $\mathrm{v}$ protsesse obucheniya derezirovaniu [Methodological aspects of the development of coordination actions of psychomotor activity of a student in the process of teaching conducting]. Voprosy muzikalnopedagogicheskogo obrazovaniya : sbornyk nauchno-metodicheskih statei kafedry peniya I khorovogo derezirovaniya MGU [Questions of music and pedagogical education: a collection of scientific and methodological articles of the Department of Singing and Choral Conducting, Moscow State University], 3, 62-65. Moskow: Ritm [In Russian].

3. Gotsdiner, A. (1993). Muzikalnaya psikhologiya [Music psychology]. Moskow: Nauka [In Russian].

4. Zaporozets, A. (1967). Izbrannie psikhologicheskie trudy. Razvitie proizvolnikh dvizeniy [Selected psychological works. Development of voluntary movements]. Moskow: Prosveshenie [In Russian].

5. Illin, E. (1990). Dvigatelnaya pamyat i pamyat na dvizeniya sininimy? [Are motor memory and movement memory synonymous?]. Voprosy psikhologii [Psychology issues], 4, 134-140 [In Russian].

6. Musin, I. (2006). Yazik dirizerskogo zesta [Conductor's gesture language]. Moskow: Muzika [In Russian].

7. Platonov, K. (1972). Problema sposobnostei [Ability problem]. Kharkov [In Russian].

8. Rubinshtein, S. (1960). Problemy sposobnostei I voprosy psikhologicheskoi teorii [The problem of abilities and questions of psychological theory]. Voprosy psikhologii [Psychology issues], 1, 47-60 [In Russian].

9. Sechenov, I. (1954). Izbrannie Trudy [Selected Works]. Moskow: Izd-vo AN SSSR [In Russian].

10. Stanislavskii, K. (1989). Rabota aktera nad soboi: sobranie sochineniy v 9 tomakh [The work of the actor on himself: collected works in 9 volumes], 2. Moskow: Iskusstvo [In Russian]. 